ADAM BARTCZAK

Uniwersytet Łódzki

\title{
OFFICIUM ET IUS W KAN. 1136 KPK
}

Treść: Wstęp. - 1. Officium et ius w porządku kanonicznym. - 2. Gravissimum officium et ius primarium. - 3. Podmiot normy. - 4. Troska o wychowanie.

\section{Wstęp}

Szczególne określenie powinności ciążącej na rodzicach odnajdujemy w kan. 1136 Kodeksu Prawa Kanonicznego z 1983 r. Prawodawca stwierdza w nim, iż rodzice mają najcięższy obowiązek i najpierwsze prawo troszczenia się zgodnie, według swoich możliwości, o wychowanie potomstwa zarówno fizyczne, społeczne i kulturalne, jak i moralne oraz religijne ${ }^{1}$. Niniejsza norma zawiera cztery istotne punkty, które zasługują na szczególną uwagę, zwłaszcza we współczesnej rzeczywistości i kulturze prawnej. Chodzi najpierw o dwa sformułowania, które nigdzie indziej w kodeksie się nie pojawiają, a mianowicie najcięższy obowiązek i najpierwsze prawo. Do tego pragnę zwrócić uwagę na określenia troska oraz wychowanie potomstwa. Bez sprzecznie wszystkie one razem stanowią o powinności wypływającej z faktu bycia rodzicem. Mamy do czynienia $z$ dwoma podmiotami o tej samej godności, ale prawnie o różnych prawach i obowiązkach.

\section{Officium et ius w porządku kanonicznym}

Prawodawca w kan. 1136 KPK przedkłada dwa terminy prawne. W tekście łacińskim są to officium et ius. W tłumaczeniu na język pol-

${ }^{1}$ Can. 1136 CIC/1983 : „Parentes officium gravissimum et ius primarium habent prolis educationem tum physicam, socialem et culturalem, tum moralem et religiosam pro viribus curandi”. 
ski brzmią one obowiązek i prawo. Wpisują się one w porządek prawno-kanoniczny. Generalnie pojęcie ius - prawa, nie przysparza problemów interpretacyjnych. Jednakże pojęcie officium nie jest już takie jednoznaczne. W Słowniku kościelnym łacińsko-polskim odnajdujemy następujące znaczenia: 1) służba, pełnienie służby; 2) służbowe stanowisko, powołanie, urząd, zakres działania, zajęcie, urzędnicy; 3) obowiązek, zobowiązanie, powinność; 4) spełnienie obowiązku, wierność, posłuszeństwo, zależność ${ }^{2}$. Słownik łacińsko-polski wymienia takie znaczenia: 1) przysługa, usługa, usługiwanie, służba, grzeczność pomoc, akt dobroczynny, łaska, gotowość świadczenia pomocy; 2) akt znamionujący szacunek, okazanie szacunku, grzeczność, uprzejmość; 3) obowiązek, powinność, powinność moralna, obowiązek moralny, poczucie obowiązku, obowiązkowość; 4) praca, funkcja, rola, zadanie; 5) powinność <zadanie, obowiązek, praca> zlecona/ne/ny < podjęta/te/ ty, zadana/ny $>$, polecenie, zlecenie, poruczenie, misja, zajęcia $<$ obowiązki> oficjalne; 6) stanowisko, urzędowanie, zatrudnienie, urząd, funkcja, służba, urzędnicy³. Jeszcze inną kolejność przedstawia natomiast Słownik łacińsko-polski dla prawników i historyków: 1) obowiązek, powinność; 2) poczucie obowiązku, obowiązkowość; 3) przyjęcie na siebie spełnienia pewnej czynności za drugiego, a dopiero na końcu 6) pełnienie służby; 7) urząd, funkcja, godność ${ }^{4}$. Przywołane określenia karzą rozumieć ten termin w dwojakim znaczeniu: dynamicznym, określającym obowiązek, powinność spełnienia, wykonania czegoś oraz statycznym związanym z konkretną funkcją, urzędem.

$\mathrm{Na}$ gruncie stosunku prawnego forma dynamiczna określa zobowiązania jednej strony wobec drugiej oraz prawa drugiej wobec pierwszej. Natomiast prawodawstwo kościelne, kanonistyka ukształtowały jedno pojęcie, które w swoim zakresie wskazuje podmiot posiadający jednocześnie prawo i obowiązek. A zatem w tym znaczeniu officium to i ius i obligatio. W próbie syntetycznego zestawienia tychże pojęć należy podkreślić, iż obligatione określa obowiązek wskazując zarówno

2 A. Jougan, Słownik kościelny łacińsko-polski, Sandomierz 2013, s. 463.

3 Stownik łacińsko-polski, t. 2, red. J. Korpanty, Warszawa 2003, s. 368.

4 J. Sondel, Słownik łacińsko-polski dla prawników i historyków, Kraków 1997, s. 687-688. 
na podmiot zobowiązany do jego spełnienia jak również podmiot na rzecz którego należy wypełnić obowiązek. Natomiast termin officium nie przedkłada już na pierwszym miejscu obowiązku spoczywającego na podmiocie, ale samo wypełnienie obowiązku związanego z podjęciem określonej funkcji ${ }^{5}$. Trzeba jednak zauważyć, iż Prawodawca nie jest konsekwentny w przytaczanej terminologii, używając zarówno officium i obligatione w tekście kodeksu.

Jeszcze jedną ważną z punktu teoretycznego kwestią pozostaje kolejność używania terminów officium et ius. Jakkolwiek najczęściej mówi się o prawach - obowiązkach, tak w Kodeksie Prawa Kanonicznego kolejność ta została odwrócona: obowiązek - prawo. Znany jest podział wśród kanonistów ze względu na poglądy dotyczące pierwszeństwa ius czy officium ${ }^{6}$. Prawodawca w kan. 1136 KPK na pierwszym miejscu stawia officium a potem ius. Czy oznacza to iż, w analizowanej normie pierwszeństwo nad prawem bierze obowiązek? Wedle założeń koncepcji pierwotności obowiązku w stosunku do prawa, to pierwotna norma moralna istniejąca w podmiocie zmieniła się w regułę prawną. Porządek prawny w Kościele przybrał charakter norm moralnych, właśnie na skutek inkorporacji Bożego prawa naturalnego nacechowanego moralnością do tego porządku. Stąd obowiązki wobec Boga i ludzi wzajemnie stały się obowiązkami prawnymi. Jak konkluduje za Piusem XI T. Gałkowski, obowiązek ma pierwszeństwo przed prawem, a podstawowym prawem staje się wypełnienie własnego obowiązku? ${ }^{7}$ Tenże Autor w innym miejscu sugeruje, iż dla lepszego zrozumienia terminu officium należałoby go tłumaczyć jako powinność.

5 T. GaŁkowski, Prawo - obowiązek. Pierwszeństwo i wspótzależność w porządkach prawnych: kanonicznym i społeczności świeckiej, Warszawa 2007, s. 47-48.

${ }^{6}$ Zob. P. Bellini, Diritti fondamentali dell'uomo. Diritti fondamentali del cristiano, w: Ephemerides Iuris Canonici 34(1978), s. 211-246; E. CorecCo, Considerazioni sul problema dei diritti fondamentali del cristiano nela Chiesa e nella società, w: Ius et Communio, Scritti di Diritto Canonico, Casale Monferrato, t. 1, s. 245-278; P. ERDö, Teologia del diritto canonico. Un approccio storico-istituzionale, Torino 1996, s. 130-138; R. Sobański, „Iura propter officia”? Remarques liees aux en-tetes de Ier et Ie titres du Livre II du nouveau CIC, w: Vita impendere vero. Studi in onore di Pio Ciprotti (Utrumque ius 14), Roma 1986, s. 221-233.

7 T. Galkowski, Prawo - obowiazek, dz. cyt., s. 424. 
A więc officium to nie obowiązek prawny, ale powinność człowieka względem Boga, który w ten sposób odpowiada na powołanie ${ }^{8}$.

\section{Gravissimum officium et ius primarium}

Przytaczane w kanonie officium i ius nabiera szczególnej rangi ze względu na ich dookreślenie. Obowiązek, powinność i prawo zostaje obciążone aksjologicznie terminami gravissimum oraz primarium. To formy przymiotników w stopniu najwyższym. Przymiotnik gravis oznacza ciężki, ważki, ważny, poważny ${ }^{9}$, natomiast primarius to jeden z pierwszych ${ }^{10}$. W polskim tłumaczeniu kodeksu odnajdujemy odpowiednio najcięższy i najpierwszy. Podobne określenia można znaleźć w kan. 226 \$2 KPK. Czytamy tam: ,Rodzice, ponieważ dali dzieciom życie, mają bardzo poważny obowiązek i prawo ich wychowania""11.

Poddając analizie proces kształtowania się tej normy możemy prześledzić kilka istotnych zmian. Kodeks z 1917 r. również w rozdziale dotyczącym skutków małżeństwa zawierał przepis odnoszący do omawianego prawa-obowiązku rodziców. W kan. 1113 czytamy: ,„Jak najusilniej obowiązani są rodzice starać się w miarę sił o wychowanie dziecka tak religijne i moralne, jak fizyczne i obywatelskie, a także troszczyć się o ich dobro doczesne"12. Prawodawca dla opisu tego obowiązku posługuje się jedynie terminem gravissima obligatione. Nowe spojrzenie na świat a tym samym na małżeństwo przyniósł Sobór Watykański II. Podkreślenie małżeństwa jako fundamentu rodziny ${ }^{13}$, oraz

8 Tamże, s. 436.

9 A. Jougan, dz. cyt., s. 288.

${ }^{10}$ Tamże, s. 539.

${ }^{11}$ Can. 226 \$2 CIC/1983: ,Parentes, cum vitam filiis contulerint, gravissima obligatione tenentur et iure gaudent eos educandi".

${ }^{12}$ Can. 1113 CIC/1917 - ,Parentes gravissima obligatione tenentur prolis educationem tum religiosam et moralem, tum physicam et civilem pro viribus curandi, et etiam temporali eorum bono providendi".

${ }^{13}$ Sobór Watykański II, Konstytucja dogmatyczna o Kościele Lumen gentium, w: Sobór Watykański II, Konstytucje, Dekrety, Deklaracje, tekst polski, Poznań 2002, n. 11, s. 114: ,Z małżeństwa chrześcijańskiego bowiem wywodzi się rodzina, a w niej rodzą się nowi obywatele społeczności ludzkiej, którzy dzięki łasce Ducha Świętego stają się przez chrzest synami Bożymi, aby Lud Boży trwał poprzez wieki. W tym 
określenie równorzędności celów małżeństwa, musiało skutkować reformą prawa małżeńskiego. W Schemacie fundamentalnego Prawa Kościoła z 1970 r., zostaje wprowadzone nauczanie Soboru. W kan. 24 $\S 2$ znalazł się następujący wpis: „Skoro rodzice dali dzieciom życie, stają się pierwszymi i głównymi ich wychowawcami, a więc mają najpoważniejszy obowiązek wychowania potomstwa i posiadają do tego prawo. Stąd też na pierwszym miejscu do chrześcijańskich rodziców należy troska o chrześcijańskie wychowanie dzieci, zgodnie z nauką przekazywaną przez Kościół"14. W projekcie kanonów o małżeństwie z 1973 r. Konsultorzy podjęli problematykę skutków małżeństwa, a zatem kan. 1113 Kodeksu z 1917 r. Pomimo, że pojawiły się wątpliwości co do zamieszczenia kanonu dotyczącego obowiązku rodziców wychowania potomstwa w części dotyczącej skutków małżeństwa, zaproponowano następujące brzmienie kanonu: „Parentes ius - seu : ius primarium - et gravissimum officium habent prolis educationem tum physicam, socialem et culturalem, tum moralem et religiosam pro viribus curandi, mediisque ad haec necessariis providendi"' ${ }^{15}$. Pierwszy

domowym niejako Kościele rodzice za pomocą słowa i przykładu winni być dla dzieci swoich pierwszymi zwiastunami wiary i pielęgnować właściwe każdemu z nich powołanie, ze szczególną zaś troskliwością powołanie duchowne”. SoBÓR WATYKAŃSKI II, Deklaracja o wychowaniu chrześcijańskim Gravissimum educationis, w: Sobór Watykański II, Konstytucje, Dekrety, Deklaracje, tekst polski, Poznań 2002, n. 6, s. 319. „Ponieważ do rodziców należy podstawowy i niezbywalny obowiązek oraz prawo wychowywania dzieci...”.

${ }^{14}$ Schemat fundamentalnego Prawa Kościoła - Schema legis Ecclesiae fundamentialis (Il Regno. Documentazione, 15.VII.1970, ss. 284-300), w: E. SzTafrowski, Posoborowe Prawodawstwo Kościelne, Dokumenty prawno-liturgiczne, t. III, z. 3, Warszawa 1971, s. 116: „Can. 24 § 2. Parentes, cum vitam filiis contulerint, primi et praecipui eorum sunt educatores, qui nempe prolem educandi gravissima obligatione tenentur et iure gaudent; parentum christianorum ideo imprimis est educationem christianam secundum doctrinam ab Ecclesia traditam filiorum curare".

${ }^{15}$ Projekt kanonów o małżeństwie - De matrimonio (Communicationes 5/1973/7093), w: E. Sztafrowski, Posoborowe Prawodawstwo Kościelne, Dokumenty prawno-liturgiczne, t. VI, z. 3, Warszawa 1975, s. 74: „De canone 1113, qui agit de obligatione parentum curandi educationem prolis, dubium motum fuit utrum recte collocatus sit sub rubrica „De effectibus matrimonii”. Obligatio enim educationis tenet omnes parentes, etiamsi non fuerint coniugati, quare coniuges eadem tenentur potius ut parentes, non ut coniuges, et obligatio educationis est effectus procreationis potius quam ma- 
raz w brzmieniu tego kanonu pojawiła się terminologia ius primarium oraz gravissimum officium. W kolejnym schemacie z 1974 r. poprawiono jedynie sam początek: „Parentes ius (primarium) et gravissimum officium ..."16. Ostatnie zmiany tekstu miały miejsce w 1977 r. Podczas kolejnego spotkania Konsultorów do przedstawionego brzmienia kanonu: ,Parentes gravissimum et ius primarium habent prolis educationem tum physicam et socialem et culturalem, tum moralem et religiosam pro viribus curandi, mediisque ad haec necessariis providen$d i$ " wprowadzono następujące zmiany. Do terminu officium dołączono określenie gravissimum oraz wycofano z tekstu przepisu ,mediisque ad haec necessariis providendi" ${ }^{17}$. Wartym podkreślenia jest fakt, iż Prawodawca przejął w kodeksie terminologię używaną już podczas prac nad nowym prawodawstwem. Na określenie najpoważniejszego obowiązku używa dwóch różnych określeń: officium i obligatio. W tekście Deklaracji o wychowaniu chrześcijańskim Gravissimum educationis, który stał się pierwowzorem normy, zostało użyte obligatio $^{18}$. Dla przykładu, w omawianym kan. 1136 oraz 914 KPK znajdu-

trimonii. Nihilominus, cum procreatio legitima in matrimonio tantum fiat, locus non mutandus videbatur".

${ }^{16}$ Can. 90 (CIC 1113). Schemat odnowionego prawa małżeńskiego - Schema iuris recogniti „De matrimonio” [Periodica 63(1974), s. 611-658], w: E. SzTAFrowski, Posoborowe Prawodawstwo Kościelne, Dokumenty prawno-liturgiczne, t. VII, z. 2, Warszawa 1977, s. 263.

${ }^{17}$ Zespół przygotowujący prawo małżeńskie - Coetus studio rum de iure matrimoniali, Adunatio diei 20 octobris 1977, (Communicationes 9, 1977, pp.117-145 et 345378), w: E. Sztafrowski, Posoborowe Prawodawstwo Kościelne, Dokumenty prawno-liturgiczne, t. XI, z. 2, Warszawa 1980, s. 297.

„Can. 332 (CIC 1113) - Parentes gravissimum et ius primarium habent prolis educationem tum physicam et socialem et culturalem, tum moralem et religiosam pro viribus curandi, mediisque ad haec necessariis providendi".

- Ante omnia mendum typographicum initio corrigitur; textus enim ita legi debet: ,parentes ,officium” gravissimum et ius ...”.

Proponitur ab aliquo Consultore ut daleantur ultima verba „,mediisque ad haec necessariis providendi”, utpote superflua. Propositio aliis Consultoribus placet.

${ }^{18}$ Concilium Oecumenicum Vaticanum II, Declaratio de educatione Christiana Gravissimum educationis, AAS 58 (1966), p. 731: „Parentes, cum vitam filiis contulerint, prolem educandi gravissima obligatione tenentur et ideo primi et praecipui eorum educatores agnoscendi sunt". 
jemy określenie officium, natomiast w powiązanych kanonach 226 §2, $774 \S 2,793$ §1,867 §1 KPK Prawodawca używa terminu obligatione. Pomimo różnicy, o której już wcześniej pisałem, wydaje się, że nie jest to celowy zabieg, ale niekonsekwencja Prawodawcy w używaniu pojęć.

Obowiązek rodzący się na skutek i ze względu na bycie rodzicem przybiera najcięższą formę. Tak przyjęta formuła normy swoje źródło ma w myśli Soboru Watykańskiego II. W Deklaracji o wychowaniu chrześcijańskim Gravissimum educationis czytamy: „Ponieważ rodzice dali życie dzieciom, w najwyższym stopniu zobowiązani są do wychowania potomstwa i dlatego należy ich uważać za pierwszych i najlepszych wychowawców"19. Ten obowiązek jest podstawowy i niezbywalny ${ }^{20}$. Małżonkowie stając się rodzicami, jak nauczał Jan Paweł II, otrzymują od Boga dar nowej odpowiedzialności. Ich miłość rodzicielska ma się stać dla dzieci widzialnym znakiem tej samej miłości Boga, „od której bierze nazwę wszelkie ojcostwo na niebie i na ziemi”"21. Ten najcięższy obowiązek wychowania wypływa właśnie z najbardziej pierwotnego powołania małżonków do uczestnictwa w stwórczym dziele Boga: rodząc w miłości i dla miłości nową osobę, która sama w sobie jest powołana do wzrostu i rozwoju, rodzice tym samym podejmują zadanie umożliwienia jej życia w pełni ludzkiego ${ }^{22}$. Papież Jan Paweł II podejmując refleksję nad rodziną określa przymioty tego obowiązku. Wylicza, że jest on pierwotny, mający pierwszeństwo w stosunku do zadań wychowawczych innych osób i jest niezbywalny ${ }^{23}$. Pierwotność obowiązku oznacza wpisania go przez Boga w naturę bycia rodzicem. Nie zależy on od chcenia czy też niechcenia osoby - rodzica. Ponadto jest niezbywalny, to znaczy nie może być jako taki całkowicie przekazany innym, ani przez innych zawłaszczony. Należy jednocześnie z wielką odpowiedzialnością podkreślić, iż ten

\footnotetext{
${ }^{19}$ Sobór Watykański II, Gravissimum educationis, n. 3.

${ }^{20}$ Tamże, n. 6.

${ }^{21}$ Jan Paweł II, Adhortacja Apostolska Familiaris consortio, w: Adhortacje Apostolskie Ojca Świętego Jana Pawła II, Kraków 1997, n. 14, s. 106-107.

${ }^{22}$ Tamże, n. 36, s. 137-138.

${ }^{23}$ Tamże.
} 
obowiązek rozpoczyna się już od samego poczęcia i trwa aż do śmierci rodziców czy dzieci ${ }^{24}$. Podkreślić raz jeszcze należy w tym miejscu naturalny charakter tego obowiązku i prawa. Nie ustaje on bowiem ani przez separację, ani przez rozwód, ani przez stwierdzenie nieważności małżeństwa ${ }^{25}$. Obowiązek naturalny jest nadrzędny wobec zobowiązań, które zostały nałożone przez prawo świeckie, choć i te winny być wypełniane sumiennie ${ }^{26}$.

Ius primarium rodzica do wychowania potomstwa swoje źródło ma w naturalnej więzi jaka łączy rodziców z potomstwem. To oni dają mu życie i dlatego to do nich należy najpierwsze prawo do podjęcia wychowania swoich dzieci. Najpierwsze prawo oznacza, że w dziele wychowania nie ma nikogo przed nimi. To przecież aplikacja prawa naturalnego. Jej potwierdzenie można odnaleźć w dokumentach kościelnych ${ }^{27}$, państwowych ${ }^{28}$ czy międzynarodowych. Wbrew ogólnej

${ }^{24}$ Por. Jan Pawel II, Przemówienie: na Zgromadzeniu Ogólnym Narodów Zjednoczonych, (2 października 1979 r.), w: Kościelne prawo publiczne, Wybór źródeł, red. M. Sitarz, M. Grochowina, M. Lewicka, A. Romanko, P. Wierzbicki, Lublin 2012, n. 21, s. 389: ,Troska o dziecko, jeszcze przed jego narodzeniem, od pierwszej chwili poczęcia, a potem w latach dziecięcych i młodzieńczych, jest pierwszym i podstawowym sprawdzianem stosunku człowieka do człowieka".

${ }^{25}$ Kan. 1154 KPK: ,ZZ chwilą zdecydowania o separacji małżonków, należy się zatroszczyć o odpowiednie utrzymanie i wychowanie dzieci".

Kan. 1689 KPK: „W wyroku należy upomnieć strony o zobowiązaniach moralnych lub także cywilnych, którymi ewentualnie będą związane jedna strona względem drugiej i wobec dzieci, co do zapewnienia utrzymania i wychowania".

${ }^{26}$ Zob. M. S. Foster, The promotion of the canonical rights of children in situations of divorce and remarriage, Washington 1994, s. 298-300; P. MAJER, Zawarcie matżeństwa kanonicznego a obowiąki naturalne wynikajace z poprzedniego zwiąku, Annales Canonici 4(2008), s. 74-76.

${ }^{27}$ Art. 5 Karta Praw Rodziny: Carta dei Diritti Della Famiglia presentata dalla Sante Sede a tutte le persone, istituzioni ed autorita interessate alla missione della famiglia nel mondo di oggi, 22 X 1983, ComCan 15(1983), nr 2, s. 140-152. Tekst polski: L'Osservatore Romano, wyd. Polskie 10 (46) 1983: „Rodzice, ponieważ dali życie dzieciom, mają pierwotne, niezbywalne prawo i pierwszeństwo do wychowania potomstwa i dlatego muszą być uznani za pierwszych i głównych jego wychowawców”. Konferencja EPISKopatu Polski, Stużyć prawdzie o matżeństwie i rodzinie, Warszawa 2009, n. 155 , s. 95.

${ }^{28}$ Art. 48. Konstytucja Rzeczypospolite Polskiej z 2.04.1997, Dz.U. 1997, Nr 78 
zasadzie pierwszeństwo w wychowaniu dzieci wcale nie zaczyna się w momencie kiedy potomstwo przychodzi na świat. Pierwszym krokiem i przykładem wielkiej odpowiedzialności rodziców jest w ogóle założenie rodziny poprzez zawarcie małżeństwa sakramentalnego. W niej to mężczyzna i kobieta tworząc nierozerwalną wspólnotę całego życia przez miłość, czułość, przebaczenie, szacunek, wierność i bezinteresowną służbą przygotowują miejsce dla potomstwa i jego harmonijnego wzrostu. To pierwszeństwo Prawodawca podkreśla w kodeksie również w innych miejscach, gdzie mówi: , Rodzice przed innymi mają obowiązek ..."29, „Jest przede wszystkim obowiązkiem rodziców ..." ’30.

Ten szczególny w swym określeniu obowiązek a zaraem prawo rodziców podkreśla bezsprzecznie cel małżeństwa, którym nie jest jedynie zrodzenie potomstwa, ale również wychowanie.

\section{Podmiot normy}

Omawiany kan. 1136 KPK wpisuje się w cały zespół norm dotyczących małżeństwa. Prawodawca umieścił ten przepis w rozdziale dotyczącym skutków małżeństwa. Nie bez przyczyny. Zgodnie z kan. 1055 KPK małżeństwo ze swej natury skierowane jest do zrodzenia i wychowania potomstwa. Potomstwo jest naturalnym celem wspólnoty mężczyzny i kobiety. Określenie adresata normy odnajdujemy już w pierwszym słowie. Bez wątpienia są nimi rodzice (parentes). Jak jednak interpretować to określenie?

Podstawowa zasada interpretacji tekstu nakazuje rozumieć tekst ustawy kościelnej według własnego znaczenia słów, rozważanego w tekście i kontekście ${ }^{31}$. Łacińskie określenie parentes użyte w tekście jest rzeczownikiem w liczbie mnogiej tłumaczonym na język polski jako rodzice a w szerszym znaczeniu przodkowie. Parens to rodzic,

poz. 483 z póź. zm.; art. 95 Kodeks Rodzinny i Opiekuńczy z 25.02.1964, Dz.U. 1964 $\mathrm{Nr} 9$ poz. $59 \mathrm{z}$ póź.zm.

${ }^{29}$ Kan. 774 § KPK.

${ }^{30}$ Kan. 914 KPK.

${ }^{31}$ Por. kan. 18 KPK. 
ojciec, matka ${ }^{32}$. Pojęcie ojca i matki nie jest jednak jednoznaczne. Można bowiem je rozróżnić ze względu na różne kryteria: biologiczne, prawne, psychologiczne, socjologiczne czy religijne. W interesującym nas temacie wydaje się wystarczające podjęcie analizy dwóch pierwszych kryteriów. Rodzicami biologicznymi (genetycznymi, faktycznymi) dziecka są tylko ci, od których pochodzi odpowiednio komórka jajowa i plemnik. Naturalną drogą poczęcia dziecka jest akt cielesny mężczyzny i kobiety. Ci faktycznie są ojcem i matką, również w przyszłości jako wychowawcy swoich dzieci.

Jednakże na skutek braku możliwości naturalnego poczęcia dziecka oraz rozwoju nauk medycznych, coraz częściej do głosu dochodzą nienaturalne metody poczęcia dziecka (wewnątrzustrojowe - in vivo lub poza ustrojowe - in vitro). W języku angielskim funkcjonuje termin Artificial Reproductive Technologies (ART), który można przetłumaczyć jako „sztuczne technologie reprodukcyjne"33. O ile dawcami komórek są małżonkowie czy konkubenci to faktycznie oni też stają się osobami, które wychowują potomstwo poczęte w takich warunkach. Sytuacja zmienia się jednakże, kiedy jedno z partnerów jest bezpłodne. Wtedy dochodzi do zapłodnienia komórki jajowej przez plemniki zupełnie innego mężczyzny, albo komórki jajowej zupełnie obcej kobiety przez plemniki mężczyzny - partnera kobiety bezpłodnej.

W kryteriach prawnych pojęcie rodzica (rodziców) funkcjonuje zarówno w prawie cywilnym ${ }^{34}$ jak i kanonicznym. Prawo kanoniczne przyjmuje jedną $\mathrm{z}$ podstawowych zasad prawa rodzinnego, zgodnie z którą mater semper certa est. W temacie ojcostwa sprawa już nie jest

${ }^{32}$ Por. A. Jougan, dz. cyt., s. 480; Słownik łacińsko-polski, dz. cyt., s. 402.

${ }^{33}$ Zob. K. SzYncel, ABC bioetyki. Sztuczne zapłodnienie. Jeśli nie in vitro, to co?, Kraków 2010.

${ }^{34}$ Zagadnienia dotyczące prawa cywilnego, jako że nie są objęte tematem artykułu, pozostawiam jedynie do indywidualnego studium. Zob. Ustawa z dnia 25 lutego 1964 r. Kodeks rodzinny i opiekuńczy, Dz. U. 1964, Nr 9, poz. 59, tekst jednolity Dz. U. z 2012, poz. 788; J. Ignatowicz, M. Nazar, Prawo rodzinne, Warszawa 2012; T. SMYczyński, Prawo rodzinne i opiekuńcze, Warszawa 2012; Władza rodzicielska i kontakty z dzieckiem, Sądowe Komentarze Tematyczne, red. J. Ignaczewski, Warszawa 2012 . 
tak łatwa i oczywista. Prawodawca w kan. 1138 §1 KPK stanowi, iż ojcem jest ten, na którego wskazuje prawny związek małżeński, chyba że przy pomocy niezbitych argumentów udowodni się co innego. W kolejnym paragrafie odnosi się do prawości pochodzenia dzieci, podając iż za dzieci prawego pochodzenia uważa się te, które się urodziły przynajmniej po 180 dniach od zawarcia małżeństwa albo w ciągu 300 dni od dnia rozwiązania życia małżeńskiego. Nadto Prawodawca w kan. 1139 rozszerza możliwość legitymizacji dzieci na ich korzyść, jednocześnie znosząc klauzulę wykluczającą możliwość uznania. Tym samym dzieci, które zostały poczęte w czasie kiedy ich rodzice nie byli w małżeństwie, zyskują prawość pochodzenia. Nie znajdziemy jednak nigdzie w kodeksie definicji rodzica (rodziców), choć termin ten wielokrotnie pojawia się w kanonach kodeksu ${ }^{35}$. Choć wprost Prawodawca tego nie określa, to można dostrzec w kodeksie sformułowanie, które pokazuje, iż termin rodzic - rodzice, należy interpretować ściśle. W kan. $793 \S 1$ KPK Prawodawca rozróżnia parentes od qui eorum locum tenent ${ }^{36}$. A zatem termin użyty w tekście kan. 1136 KPK odnosi się bez wątpienia do rodziców, którzy tworząc wspólnotę małżeńską, posiadają własne potomstwo. Ta zasada nie wypływa z prawa pozytywnego, ale z prawa Bożego naturalnego. Prawodawca kodeksu z 1983 r. Jan Paweł II zauważa, iż mężczyzna i kobieta poprzez swoje małżeńskie przymierze dają początek rodzinie. Genealogia osoby wpisuje się w rodzinę, która jest początkiem istnienia człowieka: „w biologię rodzenia wpisana jest genealogia osoby" ${ }^{\prime 37}$. To komunia mał-

${ }^{35}$ Zob. KPK z 1983 r.: kan. 101; kan. 111 §1; kan. 226 §2; kan. 529 §1; kan. 774 $\S 2$; kan. 793 §1; kan. 796; kan. 835 §4; kan. $851^{\circ} 1$; kan. 855; kan. $867 \S 1$; kan. 868; kan. $874 \S^{\circ}{ }^{\circ} 1,^{\circ} 5$; kan. 890; kan. 914; kan. $1071 \S^{\circ}{ }^{\circ} 6$; kan. 1136; kan. 1366; kan. 1478 §1-3. Por. A. Stankiewicz, Famiglia e filiazione in diritto canonico, w: Finis legis Christus. Księga pamiątkowa dedykowana Księdzu Profesorowi Wojciechowi Góralskiemu z okazji siedemdziesiątej rocznicy urodzin, red. J. Wroceński, J. Krajczyński, t. I, Warszawa 2009, s. 185-200; E. Szczot, Ochrona rodziny w prawie Kościoła łacińskiego, Lublin 2010, s. 110-112.

${ }^{36}$ Can. $793 \S 1$ CIC'1983 : „Parentes, necnon qui eorum locum tenent, obligatione adstringuntur et iure gaudent prolem educandi;".

${ }^{37}$ JAN PAwEŁ II, List do Rodzin, Rzym 1994, n. 9, w: Listy pasterskie Ojca Świętego Jana Pawła II, red. A. Sproniak, Kraków 1997, s. 261. 
żonków w miłości daje początek wspólnocie jaką jest rodzina. Dlatego tylko oni mogą nosić miano rodziców względem potomstwa jakim ich Bóg obdarza. Wynika to, jak zauważa Jan Paweł II, z szerokiego kontekstu odczytywania analogii rodzenia i rodzicielstwa: „Żadna z istot żyjących poza człowiekiem nie została stworzona „na obraz i podobieństwo Boga". Ludzkie Rodzicielstwo jest biologicznie podobne do prokreacji innych istot żyjących w przyrodzie, ale istotowo jest ,podobne" — ono jedno — do Boga samego. Takie właśnie rodzicielstwo stoi u podstaw rodziny jako ludzkiej wspólnoty życia: jako wspólnoty osób zjednoczonych w miłości (comunio personarum)"38.

Kiedy jednak małżonkowie stają się prawnymi opiekunami dziecka, choć z punktu biologicznego nie są ojcem i matką dziecka, to Prawodawca kościelny wskazuje, że mają oni to samo prawo co rodzice - prawo wychowania potomstwa. W kan. 110 KPK czytamy: „dzieci adoptowane zgodnie z przepisami prawa cywilnego uważane są za dzieci tego lub tych, którzy je adoptowali”. Oznacza to jednak zrównanie jedynie w prawach i obowiązkach, a nie w znaczeniu ścisłym. Interpretując jednak w szerokim kontekście, stosując analogię, można byłoby zaliczyć do obowiązków naturalnych prawo i obowiązek wychowania potomstwa przez osoby sprawujące jedynie rolę rodziców. Dziecko ma prawo oczekiwać spełnienia tych praw i obowiązków od sprawujących opiekę nad nim w zastępstwie rodziców, które jako officium gravissimum et ius primarium przynależą rodzicom naturlanym. Wszystkie bowiem dzieci, niezależnie od tego czy narodziły się w małżeństwie czy poza nim, posiadają takie same prawa do opieki społecznej i do troski o pełny rozwój ich osobowości ${ }^{39}$.

\section{Troska o wychowanie}

Obowiązek i prawo spoczywające na rodzicach odnosi się do troski o wychowanie potomstwa. Potomstwo jest jednym z celów małżeń-

${ }^{38}$ Tamże, s. 255.

${ }^{39}$ Art. 4 pkt. e., Karty Praw Rodziny. Por. R. Sobański, Pozycja kanoniczna osób fizycznych, w: Komenatrz do Kodeksu Prawa Kanonicznego, red. J. Krukowski, Pallotinum 2003, s. 180: „Prawo kan. zrównuje stosunek ,adoptujący - adoptowani” ze stosunkiem ,rodzice naturalni - ich dzieci”. 
stwa sakramentalnego. Jest ono naturalnie wpisane w relację mężczyzny i kobiety. Pierwszym krokiem jest współżycie seksualne zmierzające do poczęcia dziecka. Drugim zaś jest odpowiedzialne rodzicielstwo. W nie zaś włącza się troska o wychowanie potomstwa. Troska czyli dbałość o coś, zabiegania o coś. Troszczyć się to znaczy interesować się, starać się, opiekować się, pielęgnować, chronić. Troska o wychowanie, dodajmy w różnych aspektach życia o czym potem, staje się przedmiotem obowiązku i prawa spoczywającego na rodzicach. Ze względu na swoje powołanie do życia w małżeństwie, tworzenia rodziny, troska o wychowanie staje się konkretnym działaniem, odpowiedzią na treść tego powołania ${ }^{40}$. Poprzez sakrament małżeństwa, jak podkreślał Jan Paweł II, zadanie wychowawcze rodziców nabiera godności i charakteru powołania, stając się prawdziwą i w ścisłym sensie ,posługą” Kościoła w dziele budowania jego członków ${ }^{41}$. W tym sensie troska o wychowanie potomstwa ma swoje pierwotne korzenie w podejściu i akceptacji przez małżonków tego czym jest samo małżeństwo. Akceptacja przymiotów małżeństwa staje się gwarancją

${ }^{40}$ JAN PAWE⿺ II, Familiaris consortio, n. 36, s. 137-138: „Nie można zapominać, że poza tymi cechami, charakteryzującymi zadanie wychowawcze rodziców, najgłębszym i określającym je elementem jest miłość ojcowska i macierzyńska, która znajduje w dziele wychowawczym wypełnienie doskonałej służby życiu: miłość rodzicielska od początku staje się duszą, a przez to i normą, która inspiruje i nadaje kierunek całej konkretnej działalności wychowawczej, ubogacając ją tak cennymi owocami miłości, jak czułość, stałość, dobroć, usłużność, bezinteresowność i duch ofiary”.

${ }^{41}$ Tamże, n. 38, s. 141: „Doniosłość i zaszczytność wychowawczej posługi rodziców chrześcijańskich jest tak wielka, że św. Tomasz nie waha się zestawiać jej z posługą kapłańską: „Niektórzy krzewią i podtrzymują życie duchowe wyłącznie poprzez posługę duchową. To odnosi się do sakramentu kapłaństwa; inni czynią to zarówno w stosunku do życia fizycznego, jak i duchowego, co ma miejsce w przypadku sakramentu małżeństwa, w którym mężczyzna z kobietą łączą się, ażeby wydać na świat potomstwo i wychować je na chwałę Bożą". Żywa i czujna świadomość posłannictwa otrzymanego wraz z sakramentem małżeństwa pomoże rodzicom chrześcijańskim poświęcić się dziełu wychowania dzieci z wielką pogodą ducha i ufnością, a zarazem z poczuciem odpowiedzialności wobec Boga, który ich powołuje i posyła, ażeby budowali Kościół w dzieciach. W ten sposób rodzina ochrzczonych, zgromadzona razem przez Słowo i Sakrament jako Kościół domowy, staje się tak jak wielki Kościół, nauczycielem i matką". 
wypełnienia celów małżeństwa w tym omawianego wychowania potomstwa $^{42}$. Należyta troska o wychowanie zawsze swój początek ma w odpowiednim rozumieniu i przeżywaniu sakramentu małżeństwa. Nie bez przyczyny Prawodawca dodaje, iż rodzice winni troszczyć się o wychowanie zgodnie. Tak jak zgoda stwarza małżeństwo, tak też zgoda buduje małżeństwo. Zgoda małżonków, rodziców, stwarza najlepsze warunki do prowadzenia tego procesu wychowawczego. Jednomyślność rodziców stwarza dwugłos przekazywanych treści. Wszak wychowanie jest procesem świadomym i celowym mającym na celu wprowadzenie zmian i wsparcie rozwoju dziecka, ze wskazaniem na podstawowe wartości społeczno-moralne. Rozdźwięk wśród rodziców wprowadza pewne utrudnienie w przekazie tychże wartości, nie czyniąc go jednocześnie niemożliwym.

Prawodawca w omawianym kanonie wskazuje na fizyczne, społeczne i kulturalne, jak i moralne oraz religijne wychowanie potomstwa. Tym samym wskazuje na najważniejsze sfery życia ludzkiego. Z jednej strony rodzice mają gwarantować rozwój fizyczny a z drugiej duchowy. To na nich spoczywa ukształtowanie młodego człowieka w sferze społecznej i kulturowej. Jako istota społeczna musi on funkcjonować w większej społeczności. Począwszy od rodziny, w której przyszedł na świat, poprzez grupę rówieśników, pracę czy wreszcie w nowej, już własnej rodzinie. Prawodawca w kan. 795 KPK tak podkreśla Ponieważ prawdziwe wychowanie powinno objąć pełną formację osoby ludzkiej, zarówno w odniesieniu do celu ostatecznego, jak i w odniesieniu do dobra wspólnego społeczności, dlatego dzieci i młodzież tak winny być wychowywane, ażeby harmonijnie mogły rozwijać swoje przymioty fizyczne, moralne oraz intelektualne, zdobywać coraz doskonalszy zmysł odpowiedzialności, właściwie korzystać z wolności i przygotowywać się do czynnego udziału w życiu społecznym".

Pojęcie obowiązku i prawa funkcjonuje w kodeksie z 1983 r. Możemy je odnaleźć w kan. 1136. Prawodawca określa to pojęcie bardzo

${ }^{42}$ Zob. A. BARTCZAK, Nierozerwalność malżeństwa dobrem potomstwa, Studia Gdańskie 31(2012), s. 127-140. 
charakterystycznie. Czytamy najcięższy obowiązek i najpierwsze prawo. Takie określenie pada w kodeksie tylko w tym miejscu. Analiza tych pojęć wskazuje, iż forma ich wyrażenia ma swoje źródło w pojęciu rodziny. Rodzina jest pierwszym miejscem, w którym człowiek się rozwija. I to właśnie do tych, którzy dali życie, należy najcięższy obowiązek i najpierwsze prawo wychowania potomstwa. Rodzice nie mogą się go pozbyć, ponieważ wpisany jest on naturalnie w bycie matką i ojcem. I choć Prawodawca zdaje się być niekonsekwentny w użyciu terminologii officium i obligatione, to jest kontynuatorem myśli Soboru Watykańskiego II. Najcięższy obowiązek i najpierwsze prawo ciąży na rodzicach w stosunku do swoich dzieci, zarówno tych pochodzenia naturalnego jak i tych pochodzących z adopcji. I choć mamy do czynienia z przepisem kościelnym, to bez wątpienia norma w nim zawarta ma charakter naturalny.

\section{Officium et ius in the can. 1136 Code of Canon Law}

The concept of the duty and the right functions in the Code of Canon Law. We can found it in the can. 1136. The Legislator defines this concept very characteristic. In this canon following some phrase: gravissimum officium et ius primarium. Such a definition in the Code is only at this point. It is true that the Legislator is not consistent in the use of this terminology. The analysis of that term indicates that the form of expression has its source in the concept of family. The family is the first place where the person develops. Those who gave life have the heaviest duty and the very first right to educate their offspring. Parents can not get rid of it because it is naturally inscribed to be a mother and a father.

SŁowA KLUCZowE: małżeństwo, rodzice, prawo, obowiązek, dzieci

KEY WORDS: marriage, parents, duty, right, children 